\title{
Constraints to Local Government Performance n Agricultural Development in Anambra State, Nigeria
}

\author{
Nwalieji H.U.*, Igbokwe E. M. ** and Okeke M.N. * \\ Department of Agricultural Economics and Extension, Anambra State University, Igbariam \\ Campus, Nigeria* \\ Department of Agricultural Extension, University of Nigeria, Nsukka** \\ Corresponding e-mail: nwaliejihyacinth@yahoo.com \\ Phone Number: 07033994751
}

\section{Abstract}

The purpose of the study was to identify constraints to local governments' role performance in agricultural development in Anambra State of Nigeria. The population of the study consisted of all the local government staff in the agriculture and veterinary department in the 21 LGAs of Anambra State. One management staff (head of department agriculture) and five (5) field staff from other cadres were purposively and randomly selected, respectively, giving a total of 60 respondents. Questionnaire and field observations were used for data collection. Frequency, percentage, mean score and factor analysis were used to analyze data. The mean age of the staff was $42.5 y e a r s$ while majority $(70.0 \%)$ was female and the mean of work experience was 18.33 years. Most LGs' roles in agricultural development had not been accomplished to great extent. Only provision of slaughter houses and slabs, establishment of market gardens, mobilization of farmers for cooperatives and procurement and distribution of fertilizer, improved seeds, improved seedlings, tractors and implements among others were perceived as accomplished to very great extent. All the 24 identified problems were serious, and four problems were factored as political, manpower, operational, and logistic problems.

\section{Introduction}

Development of the grassroots has been the concern of every responsible and responsive political system. However, development and participation have continued to elude people at the grassroots. Development remains insignificant if it does not positively affect the lives of those in the periphery of decision making arrangement (Arowolo, 2008). The Nigerian state therefore created the LG as the third tier of government whose objective is to ensure effective, measurable and efficient service delivery to the people. The LGCs are responsible for agricultural and rural development in their areas of jurisdiction as stipulated in the 1999 Constitution and the 1976 Guidelines of the Federal Republic of Nigeria. Most projects' and programmes' implementation are mainstreamed within LGC structure, with trainings and other technical assistance provided to strengthen them. However, there are six standardized departments in a LGC within which the agricultural department is one, each with a supervisor and head of department who is a career civil servant. The responsibilities of the agricultural department are overall agricultural development, including crops, livestock, fisheries and agro-forestry/forestry plantation development (IDB, 2007).

Okpala (2003) notes that the greater percentage of people in Anambra State representing over $80 \%$ of the entire populace live in rural areas of the state and farming still remains the major occupation of the greater number of the population. A large proportion of the citizens are still tilling the soil with crude implements. This according to Anolue (2004) should be the concern of the agricultural departments in each of the LGAs of the state. However the impact and presence of the LG agricultural departments are not felt in most of the LGAs of the state thereby making agricultural transformation agenda difficult to attain. The question relates to the role performance of the $L G$ and the problems inhibiting their role 
performance in the area of agriculture. What roles have LGs been able to accomplish; and what are the problems inhibiting their role performance in boosting agricultural production in Anambra state?

\section{Purpose of the study}

The main purpose of the study was to identify the constraints to local governments' role performance in agricultural development in Anambra State of Nigeria. Specifically, the study was designed to:

i. identify the roles LGs have been able to accomplish; and

ii. Identify factors inhibiting the role performance of LGs.

\section{Methodology}

The study area was Anambra State of Nigeria. It is made up of 21 LGAs. Among the LGs, only five (5) (Awka South, Idemili North, Onitsha North, Onitsha south and Nnewi North) are said to be urban local governments, while the remaining are rural (Anolue, 2004). The major food baskets of the state among the LGs are Anambra East, Anambra West, Awka North, Ayamelum, Ogbaru, Orumba North and South and Oyi LGs. Anambra State occupies on area of $4,416 \mathrm{sq}$. $\mathrm{km}$. Seventy percent is arable land and less than 55 percent of this arable land is under cultivation. Crops, livestock and fisheries are main stock in the farming system of the state. Off-farm activities like processing and marketing are also vital components. Currently, there are seven (7) recognized departments in the local government system in Anambra State and these include: Administration/Personnel; Agriculture and Veterinary; Education and Social Welfare; Health and Environment; Works; Finance; and (recently approved) Planning and Statistics. Agriculture and Veterinary Department is one department manned by Head of Agriculture Department (HOD Agriculture).

All the LG staff in the agriculture and veterinary department in the 21 LGAs of Anambra State comprised the population of the study. Out of this, about 50 percent, that is 10 LGAs were purposively selected. These included the nine (9) National Programmes on Food Security (NPFS) participating LGs and one (1) LG (Anambra West) of the eight major food baskets of the state. One management staff (HOD Agriculture) and five (5) field staff from other cadres were purposively and randomly selected respectively, each from the agriculture and veterinary department. This gave a total sample of 60 respondents. A questionnaire and field observations were used to collect data for the study.

\section{Measurement of variables}

Objective 1 aimed at identifying the roles LGs have been able to accomplish. Here the respondents were asked to indicate on a 5-point- Likert type scale the extent the shortlisted roles have been accomplished. Their response categories and the corresponding weighted values were as follows: to a great extent (TGE) $=5$; to some extent (TSE) $=4$; to little extent $(T L E)=3$; to very little extent $(T V L E)=2$; to no extent $(T N E)=1$. These values were added to obtain a value of 15 which was divided by 5 to get a mean score of 3.0. The respondents mean was obtained on each of the items. Any mean score $\geq 3.0$ was regarded as role accomplished to great extent, while any mean score $<3.0$ was regarded as role not accomplished. Objective 2 sought to identify factors inhibiting the role performance of local governments. To achieve this, the respondents were asked to indicate on a 4-point Likert type scale, how serious each of the various factors inhibit the role performance of the local governments in the study area. Their response categories were; very serious (VS) $=4$; quite serious $(Q S)=3$; somewhat serious $(S S)=2$; and not serious $(N S)=1$. Any mean score equal to or greater than 2.5 was regarded as very serious problem; while any mean score less than 2.5 was regarded as not serious problem. 
Also data was subjected to exploratory factor analysis procedure, using the principal factor model with varimax rotation in grouping the constraint variables into major constraint factors. However, only variables with loadings of 0.4 and above (10\% overlapping variance) were used in naming the factors. Personal characteristics were presented using frequencies, percentages and mean scores. Objective 1 was analyzed using mean statistic while objective 2 was analyzed using explanatory factor analysis procedure.

\section{Results and Discussion}

\section{Personal characteristics of the respondents}

Table 1 shows that greater proportion (50.0\%) of the staff were between the age ranges of 41 to 50 years. This was followed by $40.0 \%$ of them whose age ranges from 31 to 40years while the remaining $(10.0 \%)$ staff were between the age ranges of 51 to 60 years. The mean age of the respondents was 42.5 years. This implies that majority of the staff are still within their middle age and have not reached or neared their retirement age. It is evident from Table 1 that majority $(70.0 \%)$ of the staff were female while $30.0 \%$ were male. The result implies that the local government staffs are predominantly female. Table 1 also indicates that at first appointment $30.0 \%, 20.0 \%, 20.0 \%$ and $30.0 \%$ of the respondents had WAEC/GCE, OND/NCE, HND and degree certificates respectively. Also the table shows that majority $(50.0 \%)$ of the respondents at current obtained degree certificates and this was followed by $28.3 \%$ who had HND while the remaining (18.3\% and $3.3 \%$ ) obtained OND/NCE and M.Sc. respectively. This implies that there were great educational advancements by the respondents from the date of first appointment to date.

Table 1: Percentage distribution of the respondent according to their socio-economic characteristics

\begin{tabular}{lll}
\hline Variables & $\begin{array}{l}\text { Percentage } \\
(\%)\end{array}$ & Mean (M) \\
\hline Age (years): & 40.0 & \\
$31-40$ & 50.0 & 42.50 \\
$41-50$ & 10.0 & \\
$51-60$ & & \\
Sex: & 30.0 \\
$\quad$ Male & 70.0 \\
Female & & \\
Educational qualification at 1 ${ }^{\text {st }}$ & 30.0 \\
appointment: & 20.0 \\
$\quad$ WAEC/GCE & 20.0 \\
OND/NCE & 30.0 \\
$\quad$ HND & \\
Degree & \\
Current educational qualification & 18.3 \\
obtained: & 28.3 \\
$\quad$ OND/NCE & 50.0 \\
HND & 3.3 \\
Degree & \\
$\quad$ M.Sc. &
\end{tabular}




\section{Extent of LGs role accomplishment}

Table 2 also shows that the following LGs roles; establishment of demonstration plots $(M=3.00)$, provision of slaughter houses and slabs $(M=4.25)$, establishment of market gardens $(M=3.00)$, provision of health centre and clinics $(M=3.87)$, mobilization of farmers for cooperatives organizations and formation $(M=3.40)$, procurement and distribution of fertilizers $(M=4.67)$, improved seeds $(M=3.33)$, improved seedlings $(M=3.17)$, tractors and implements $(\mathrm{M}=3.97)$, awareness creation through exhibition of agricultural productsagricultural shows, farming seasons, tree planting and field days programmes $(\mathrm{M}=4.83)$,participation and coordination of agricultural development projects and programmes at local level $(M=4.43)$, and agricultural staff training and workshops $(M=4.33)$ were accomplished to very great extent. The remaining roles with weighted mean score less than $3.00(M<3.00)$ were said to be unaccomplished. The finding implies that $L G$ did not accomplish most of the roles accorded to them by the law establishing them thereby performed beyond expectation in the area of agricultural development in the study area. The finding is in an agreement with Anolue (2004) who observed that the impact and presence of the LG agricultural departments are not felt in most of the LGAs of the state apart from the occasional procurement and sale of fertilizers, maintenance of flowers and hedges at the local government secretariats and may be meat inspection at various markets in the locality. 
Table 2: Mean distribution of respondents according to the extent of role accomplishment

\begin{tabular}{|c|c|}
\hline LG role & $\begin{array}{l}\text { Extent of role } \\
\text { accomplishment(M) }\end{array}$ \\
\hline Provision of agricultural extension services & 2.65 \\
\hline Provision of animal health extension services & 2.58 \\
\hline $\begin{array}{l}\text { Control and acquisition of land for new entrants into } \\
\text { farming }\end{array}$ & 2.13 \\
\hline \multicolumn{2}{|l|}{ Provision of rural infrastructure: } \\
\hline Road network or good feeder roads & 2.93 \\
\hline Processing plants & 2.30 \\
\hline Storage facilities & 1.92 \\
\hline Transport and communication facilities & 1.95 \\
\hline water scheme-borehole & 2.58 \\
\hline establishment of demonstration plots & $3.00^{*}$ \\
\hline (vii) Schools & 2.68 \\
\hline (viii) Provision of veterinary clinics & 2.10 \\
\hline (ix) Provision of markets & 2.50 \\
\hline (x) Provision of slaughter houses and slabs & $4.25^{\star}$ \\
\hline (xi) Parks & 2.50 \\
\hline (xii) Market gardens & $3.00^{*}$ \\
\hline (xiii) provision of health centre and clinic & $3.87^{*}$ \\
\hline \multicolumn{2}{|l|}{ e) Mobilization of farmers for cooperative } \\
\hline $\begin{array}{l}\text { organizations and formation; farmer/community } \\
\text { associations }\end{array}$ & $3.40^{*}$ \\
\hline \multicolumn{2}{|l|}{ Procurement and distribution of agricultural inputs } \\
\hline such as: & $4.67^{*}$ \\
\hline i) Fertilizers & 2.25 \\
\hline ii) Agro-chemicals & $3.33^{*}$ \\
\hline iii) Improved seeds & $3.17^{*}$ \\
\hline iv) Improved seedlings & 1.83 \\
\hline v) Improved breeds of livestock & $3.97^{*}$ \\
\hline vi)Tractors and implements & 2.70 \\
\hline $\begin{array}{l}\text { vii)Veterinary drugs and vaccines } \\
\text { viii)Aaricultural credits }\end{array}$ & 2.25 \\
\hline $\begin{array}{l}\text { Promotion of viable agro-based projects such as snail, } \\
\text { fish, poultry farming etc. }\end{array}$ & 2.42 \\
\hline Coordination of data collection at primary levels & 1.97 \\
\hline $\begin{array}{l}\text { Awareness creation through exhibition of agricultural } \\
\text { products- shows, farming seasons, tree planting and } \\
\text { field days }\end{array}$ & $4.83^{*}$ \\
\hline $\begin{array}{l}\text { Participation and coordination of agricultural } \\
\text { development projects and programmes at local level } \\
\text { Manpower training and organization: }\end{array}$ & $4.43^{*}$ \\
\hline $\begin{array}{l}\text { Rural youth, women and farmers training on various } \\
\text { agricultural enterprises }\end{array}$ & 2.83 \\
\hline Agricultural staff training and workshops & $4.33^{*}$ \\
\hline
\end{tabular}

${ }^{*}$ = role accomplished to great extent; $M \geq 3.00$ 


\section{Factors inhibiting role performance of LGs in the study area}

Table 3 shows the mean distribution of identified problems that inhibited the role performance of LGs. The table however reveals that all the 24 identified problems inhibitors were very serious $(M \geq 2.50)$. This implies that many factors abound that militate against role performance of LGs in agricultural development. This is in support of Mkparu (2008) who noted that a number of factors have been identified as the reasons for the inability of the LGCs to have lived up to expectations in spite of the deep pool of resources (human and material) "supposedly" available to most of them. These factors according to him include: (i) the current of contracting out the revenue windows of LGCs by the state governments; (ii) the issue of poor staffing; (iii) general poor attitude to work of our people, (iv) the issue of constituting of the council with people who are alienated from the culture of the people such as elected and appointed officials; and (iv) lack of transparency and accountability which induce high incidence of corruption and corrupt practices.

Table 3: Mean distribution of identified problems inhibiting role performance of LGs in the study area

\begin{tabular}{|c|c|c|}
\hline Problems & Mean(M) & $\begin{array}{l}\text { Std. } \\
\text { Deviation }\end{array}$ \\
\hline Poor staff remuneration and allowances & $3.63^{*}$ & 0.551 \\
\hline Poor extension services-poor coverage & $3.72^{*}$ & 0.524 \\
\hline Marginalization of agricultural departments & $3.53^{*}$ & 0.700 \\
\hline Lack of derive amongst heads of agricultural departments & $3.35^{\star}$ & 0.840 \\
\hline $\begin{array}{l}\text { Corruption and corrupt practices among managements and } \\
\text { staff }\end{array}$ & $3.53^{*}$ & 0.700 \\
\hline Poor and shortage of skilled manpower/ extension personnel & $3.60^{*}$ & 0.741 \\
\hline $\begin{array}{l}\text { Lack of rural farmers participation in a programme } \\
\text { development }\end{array}$ & $3.05^{\star}$ & 0.946 \\
\hline Lack of understanding the philosophy of the LG system & $2.83^{*}$ & 1.044 \\
\hline $\begin{array}{l}\text { Existence of role duplication and overlapping of functions } \\
\text { among the tiers of government }\end{array}$ & $2.82^{*}$ & 0.965 \\
\hline $\begin{array}{l}\text { Poor funding of agricultural developmental activities both in } \\
\text { quantum and release pattern }\end{array}$ & $3.52^{*}$ & 0.701 \\
\hline Inadequate budget allocation to agricultural departments & $3.47^{*}$ & 0.724 \\
\hline Inadequate extension training & $3.30^{*}$ & 0.962 \\
\hline Inadequate availability of inputs or poor inputs supply & $3.42^{*}$ & 0.829 \\
\hline Inadequate planning and evaluation of extension programmes & $3.45^{*}$ & 0.699 \\
\hline Lack of local government autonomy & $3.37^{*}$ & 0.863 \\
\hline Instability of the political climate & $3.53^{*}$ & 0.769 \\
\hline Insecurity of investment & $3.45^{\star}$ & 0.811 \\
\hline Poor logistic support for field staff & $3.28^{*}$ & 0.993 \\
\hline Politicizing of project sitting and objective & $3.37^{*}$ & 0.758 \\
\hline High cost of production & $3.33^{*}$ & 0.857 \\
\hline $\begin{array}{l}\text { Lack of quick or immediate cash return from most agricultural } \\
\text { projects }\end{array}$ & $3.27^{*}$ & 0.936 \\
\hline Poor job description of staff & $3.40^{*}$ & 0.887 \\
\hline Ineffectiveness of agricultural policies and regulations & $3.02^{*}$ & 1.097 \\
\hline
\end{tabular}




\begin{tabular}{|c|c|c|}
\hline Problems & Mean(M) & $\begin{array}{l}\text { Std. } \\
\text { Deviation }\end{array}$ \\
\hline Poor staff remuneration and allowances & $3.63^{*}$ & 0.551 \\
\hline Poor extension services-poor coverage & $3.72^{*}$ & 0.524 \\
\hline Marginalization of agricultural departments & $3.53^{*}$ & 0.700 \\
\hline Lack of derive amongst heads of agricultural departments & $3.35^{*}$ & 0.840 \\
\hline $\begin{array}{l}\text { Corruption and corrupt practices among managements and } \\
\text { staff }\end{array}$ & $3.53^{*}$ & 0.700 \\
\hline Poor and shortage of skilled manpower/ extension personnel & $3.60^{*}$ & 0.741 \\
\hline $\begin{array}{l}\text { Lack of rural farmers participation in a programme } \\
\text { development }\end{array}$ & $3.05^{*}$ & 0.946 \\
\hline Lack of understanding the philosophy of the LG system & $2.83^{*}$ & 1.044 \\
\hline $\begin{array}{l}\text { Existence of role duplication and overlapping of functions } \\
\text { among the tiers of government }\end{array}$ & $2.82^{*}$ & 0.965 \\
\hline $\begin{array}{l}\text { Poor funding of agricultural developmental activities both in } \\
\text { quantum and release pattern }\end{array}$ & $3.52^{*}$ & 0.701 \\
\hline Inadequate budget allocation to agricultural departments & $3.47^{*}$ & 0.724 \\
\hline Inadequate extension training & $3.30^{*}$ & 0.962 \\
\hline Inadequate availability of inputs or poor inputs supply & $3.42^{*}$ & 0.829 \\
\hline Inadequate planning and evaluation of extension programmes & $3.45^{*}$ & 0.699 \\
\hline Lack of local government autonomy & $3.37^{*}$ & 0.863 \\
\hline Instability of the political climate & $3.53^{*}$ & 0.769 \\
\hline Insecurity of investment & $3.45^{*}$ & 0.811 \\
\hline Poor logistic support for field staff & $3.28^{*}$ & 0.993 \\
\hline Politicizing of project sitting and objective & $3.37^{*}$ & 0.758 \\
\hline High cost of production & $3.33^{*}$ & 0.857 \\
\hline $\begin{array}{l}\text { Lack of quick or immediate cash return from most agricultural } \\
\text { projects }\end{array}$ & $3.27^{*}$ & 0.936 \\
\hline Poor job description of staff & $3.40^{*}$ & 0.887 \\
\hline Ineffectiveness of agricultural policies and regulations & $3.02^{*}$ & 1.097 \\
\hline Poor general attitude to work of our people & $3.35^{\star}$ & 0.899 \\
\hline
\end{tabular}

${ }^{*}=$ very serious problems, $M \geq 2.50$

Exploratory factor analysis was however used to group the variables into possible factors for major factors inhibiting the role performance of LGs in the study area as shown in Table 4. From data in Table 4, four problem factors were extracted based on the response of the respondents. Factors, 1, 2, 3, and 4 were named political, manpower, operational, and logistic problems respectively.

Items with high loading under factor 1 "political problems" included: lack of rural farmers participation in a programme development (0.678), inadequate budget allocation to agricultural department (0.584), inadequate planning and evaluation of extension programmes (0.724), lack of local government autonomy $(0.730)$, and instability of the political climate $(0.535)$. While in factor 2 "manpower problems", the dominating variables were: lack of derive amongst head of agriculture departments (0.451), poor and shortage of skilled manpower/ extension personnel (0.660), insecurity of investment (0.823), lack of 
quick or immediate cash return from most agric. projects (0.600), and ineffectiveness of agricultural policies and regulations (0.560).

Factor 3 "operational problems" was dominated by lack of understanding the philosophy of the L.G. System (0.614), existence of role duplication and overlapping of functions among the tiers of government (0.725), inadequate availability of inputs or poor inputs supply (0.531), high cost of production (0.636), and poor job description of staff (0.433). Specific issues with the high loadings under Factor 4 "logistic problems" included: poor staff remuneration and allowances (0.653), poor extension services such as poor coverage (0.582), marginalization of agriculture department (0.829), Poor funding of agricultural developmental activities both in quantum and release pattern $(-0.511)$, poor logistic support for field staff (0.504), and poor general attitude to work by our people (0.403).

The implication of the findings is that LGC can never perform very efficient and effective unless the problems of politics, manpower, operation and logistic are tackled and addressed. These are the major hindrances to LGC role performance in the study area. For instance, most of programmes and programme activities in the LGC are politicized thereby discouraging rural farmers' participation. Also little fund is allocated to agricultural department and field staff are not well remunerated, thereby hindering agricultural development in the area. These findings are in agreement with Gumel (2009), Igbuzor (2007) and Arowolo (2008) who observed that the factors that inhibit the performance of the LGCs are multifaceted. The most important factors are those that hinge on: (i) operational factors arising directly from the behaviour and attitude of the persons operating the system i.e. politicization distribution of amenities in the LGCs; (ii) excessive state government control of and interference in the activities of the LGCs; (iii) the phenomenon of bribery, corruption and inefficiency on the part of some LG officials; (iv) staffing problems ; (v) electoral irregularities seldom allows for credible candidates to be elected at the LGCs elections; and (vi) inadequate funding. 
Table 4: Major factors inhibiting the LGs role performance in agricultural development in Anambra state

Problems inhibiting LGs role performance

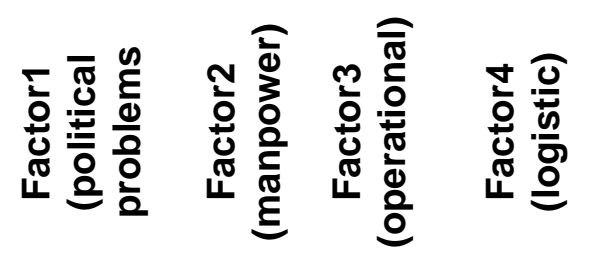

\begin{tabular}{|c|c|c|c|c|}
\hline Poor staff remuneration and allowances & -0.009 & 0.039 & 0.354 & 0.653 \\
\hline Poor extension services-poor coverage & 0.094 & 0.192 & -0.063 & 0.582 \\
\hline Marginalization of agricultural departments & -0.024 & -0.255 & 0.225 & 0.829 \\
\hline $\begin{array}{l}\text { Lack of derive amongst heads of agricultural } \\
\text { departments }\end{array}$ & -0.279 & 0.451 & 0.161 & -0.039 \\
\hline $\begin{array}{l}\text { Corruption and corrupt practices among managements } \\
\text { and staff }\end{array}$ & 0.462 & 0.413 & 0.204 & -0.158 \\
\hline $\begin{array}{l}\text { Poor and shortage of skilled manpower/ extension } \\
\text { personnel }\end{array}$ & 0.327 & 0.660 & 0.237 & -0.072 \\
\hline $\begin{array}{l}\text { Lack of rural farmers participation in a programme } \\
\text { development }\end{array}$ & 0.678 & 0.099 & 0.186 & -0.133 \\
\hline Lack of understanding the philosophy of the LG system & 0.322 & -0.159 & 0.614 & 0.056 \\
\hline $\begin{array}{l}\text { Existence of role duplication and overlapping of } \\
\text { functions among the tiers of government }\end{array}$ & -0.234 & -0.027 & 0.725 & -0.044 \\
\hline $\begin{array}{l}\text { Poor funding of agricultural developmental activities } \\
\text { both in quantum and release pattern }\end{array}$ & 0.273 & 0.148 & 0.146 & -0.511 \\
\hline Inadequate budget allocation to agricultural department & 0.584 & 0.024 & -0.138 & 0.005 \\
\hline Inadequate extension training & 0.252 & 0.206 & 0.230 & 0.174 \\
\hline Inadequate availability of inputs or poor inputs supply & 0.035 & 0.047 & 0.531 & 0.294 \\
\hline $\begin{array}{l}\text { Inadequate planning and evaluation of extension } \\
\text { programmes }\end{array}$ & 0.724 & 99 & 39 & -0.059 \\
\hline Lack of local government autonomy & 0.730 & -0.102 & -0.035 & 0.173 \\
\hline Instability of the political climate & 0.535 & 0.264 & -0.160 & 0.167 \\
\hline Insecurity of investment & 0.074 & 0.823 & -0.101 & 0.141 \\
\hline Poor logistic support for field staff & 0.393 & 0.071 & -0.148 & 0.504 \\
\hline Politicizing of project sitting and objective & 0.385 & 0.005 & 0.175 & 0.165 \\
\hline High cost of production & -0.180 & 0.232 & 0.636 & -0.031 \\
\hline $\begin{array}{l}\text { Lack of quick or immediate cash return from most } \\
\text { agricultural projects }\end{array}$ & 0.153 & 0.600 & 0.370 & -0.054 \\
\hline Poor job description of staff & 0.343 & 0.299 & 0.433 & -0.089 \\
\hline Ineffectiver & -0.061 & 0.560 & -0.150 & 0.091 \\
\hline Poor general attitude to work of our people & 0.211 & 0.288 & 0.048 & 0.403 \\
\hline
\end{tabular}

Extraction Method: Principal Component Analysis.

Rotation Method: Varimax with Kaiser Normalization. 


\section{Conclusion and Recommendation}

Based on the findings of the study, the following conclusions were arrived at: Majority were females; they have long year of work experience and have acquired more additional educational and training qualifications. Very few of the roles were accomplished; and the 24 identified problems inhibitors were very serious, and in the rotated component matrix, four problems were factored: political, manpower, operational, and logistic problems. These problems are said to have made agricultural transformation non attainable at grassroots in the study area. It is recommended that efforts should be geared toward full implementation of the most roles accorded to LGs in agricultural development; and the problems posed by political, manpower, operational, and logistic should be curbed in order to make the third tier viable and agricultural transformation agenda attainable.

\section{References}

Anolue, M. (2004). Local government agricultural departments as a centerpiece for increased agricultural production in Anambra State. Paper presented to Agricultural Department, Local government Service Commission Awka, Anambra State, Nigeria.

Arowolo, D. (2008). Local government administration and the challenges of rural development in Nigeria. http: /www.articlesbase.com/leadershiparticles.html. Retrieved on $17 / 09 / 2011$.

Gumel, L.S. (2009). Viability of LGCs under democratic system. Paper presented at National Workshop on strategies for Managing Democratic Dividend at the LG Level, held at Abuja. http://www.articles.base.com/Leadership.articles.html. Retrieved on 17/09/2011.

Igbuzor, O. (2007). Local government reform and constitutional review in Nigeria. http://www.gamiji.com/NEWS.2676.htm. Retrieved on 17/09/2011.

Islamic Development Bank (IDB) (2007). Staff appraisal report on national programme for food security (NPFS), expansion phase support project Nigeria country Operation Development: Oct.

Madukwe, M. C. (2008). Role of local government in Fadama III. Paper presented at Workshop held at Abuja, 17 November.

Mkparu, J. (2008). Repositioning the local government systems for improved service delivery and performance culture. Paper presented at seminar organized by the Anambra State LGSC, Awka held at Nteje, Oyi LG headquarters, Nteje: 3 - 5 March.

Okpala, J.E.A. (2003). Revenue generation from landscaping, professional advice and service to farmers in agricultural department of local government systems in Anambra State. Paper presented at workshop on making Agriculture Department a Revenue Yielding Arm of the LG, held at Awka South LG, 14-15 Sept. 